Jurnal Bidan Cerdas
e-ISSN: 2654-9352 dan p-ISSN: 2715-9965
Volume 3 Nomor 4, 2021, Halaman 159-167
DOI: 10.33860/jbc.v3i4.535
Website: http://jurnal.poltekkespalu.ac.id/index.php/JBC
Penerbit: Poltekkes Kemenkes Palu

\title{
Faktor Pendukung Pendewasaaan Usia Perkawinan
}

\author{
Wulan Angraini $\square \mathbb{D}^{1}$, Hilma Amrullah $\mathbb{1}^{2}$, Henni Febriawati@1, Riska Yanuarti@1 \\ ${ }^{1}$ Fakultas IImu Kesehatan, Universitas Muhammadiyah Bengkulu, Indonesia \\ ${ }^{2}$ Pusat Penelitian dan Pengembangan KB dan KS, BKKBN, Indonesia
}

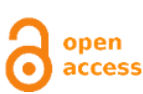

\section{ARTICLE INFO} Article History: Received: 2021-09-13 Accepted: 2021-11-19

Published: 2021-11-30

Kata Kunci: Indeks kekayaan; Jenis kelamin; Pendewasaan Usia Perkawinan; Remaja; Tempat tinggal.

\section{Keywords:}

Wealth Index; Gender; Marriage Age Maturity; Teeneger; Residence.
Email: wulanangraini@umb.ac.id

\begin{abstract}
ABSTRAK
Pendahuluan: Pendewasaan usia perkawinan (PUP) berperan penting dalam pelaksanaan program pembangunan kependudukan dan keluarga berencana yang bertujuan meningkatnya kualitas hidup. Proporsi remaja di Provinsi Bengkulu yang mengetahui tentang pembangunan keluarga masih di bawah angka nasional yaitu hanya $61,67 \%$. Tujuan: Diketahui faktor pendewasaan usia perkawinan di Provinsi Bengkulu. Metode: Desain penelitian cross sectional dengan menggunakan data sekunder Survei Kinerja Akuntabilitas Program Remaja dan Keluarga. Penelitian Juli sampai dnegan Desember 2020. Populasi penelitian merupakan keluarga yang berhasil diwawancarai pada saat petugas mendatangi rumah penduduk yang berjumlah 69.662 keluarga. Sampel adalah remaja yang bertempat tinggal di wilayah Bengkulu berjumlah 341 orang. Analisis data univariabel, analisis bivariabel chi-square. Hasil: $71.6 \%$ remaja di Provinsi Bengkulu merencanakan menikah pada saat berusia 21 tahun wanita dan 25 tahun pria. Jenis kelamin merupakan faktor pendukung yang berpengaruh terhadap pendewasaan usia perkawinan ( $p=0,013$ OR: $1,89 \mathrm{Cl} 95 \%$ : 1,16-3,07). Tempat tinggal $(p=0,374)$ dan indeks kekayaan remaja $(0,491)$ tidak berpengaruh terhadap pendewasaan usia perkawinan. Kesimpulan: Pemahaman terkait usia ideal menikah perlu diberikan sedini mungkin untuk mencegah pernikahan di usia anak. Intervensi terkait pendewasaan usia perkawinan di wilayah pedesaan perlu ditingkatkan bagi remaja melalui PLB yang perpanjangan BKKBN.
\end{abstract}




\section{PENDAHULUAN}

Isu penting yang berkembang di lingkungan masyarakat pada saat ini adalah masalah kependudukan. Laju pertumbuhan penduduk yang mengalami peningkatan tidak seiring dengan meningkatnya kualitas penduduk berdampak timbulnya masalah baru pada era pembangunan nasional. Pendewasaan Usia Perkawinan (PUP) sebagai salah satu pondasi keputusan kebijakan untuk dapat mengurangi laju pertumbuhan penduduk (Badan Kependudukan dan Keluarga Berencana Nasional (BKKBN), 2010). Himbauan program KKBPK remaja diharapkan menikah pada saat berusia yang layak yaitu berusia diatas 21 tahun bagi perempuan dan laki-laki pada saat berusia 25 tahun, bertujuan telah siap secara kesehatan, mental, dan ekonomi. Perempuan yang memutuskan untuk nikah di usia dini artinya akan berisiko anak yang dilahirkan pada saat organ reproduksi perempuan belum sempurna dan layak bereproduksi. Risiko yang dapat ditimbulkan dari keputusan melahirkan pada usia muda berakibat pada kesehatan ibu dan bayi serta berisiko terjadinya kematian ibu dan bayi (SKAP, 2019).

Tingkat ekonomi keluarga yang berada pada garis kemiskinan merupakan alasan seseorang memutuskan untuk menikah pada usia dini, mereka beranggapan dengan menikah maka akan membantu perekonomian orang tuanya. Mengingat pentingnya meningkatkan pengetahuan remaja tentang risiko menikah di usia muda, maka perlu dilakukannya pendidikan kesehatan reproduksi termasuk penundaan usia pernikahan agar tumbuh kesadaran yang tinggi bagi remaja dalam pengmbilan keputusan untuk berkeluarga (Khayati, Sundari, \& Dewi, 2020). Sejalan dengan penelitian sebelumnya yang menyimpulkan bahwa sikap remaja terhadap pendewasaan usia perkawinan dipengaruhi oleh pengetahuan remaja (Istawati, 2019).

Periode tahun 2008 sampai dengan 2018 pernikahan anak perempuan di Indonesia sebelum usia 18 tahun dan 15 tahun mengalami tren penurunan dengan kategori lambat. Penurunan angka prevalensi pernikahan anak hanya sebesara 3,5 poin persen tahun 2008 14,67\% menjadi 11,21\% pada tahun 2018. Ada sekitar 1 dari 9 wanita berumur 20-24 tahun yang menikah pertama sebelum berusia 18 tahun (UNICEF, Badan Pusat Statistik (BPS), \& Badan Perencanaan Pembangunan Nasional (Pappenas), 2020). Menurut data SKAP (2019) rata-rata remaja berencana menikah diumur $>21$ tahun adalah sebanyak $24,6 \%$ (nasional 24,4 tahun) namun yang mengatakan tidak tahu $17,8 \%$ dan $0,9 \%$ berencana menikah $<20$ tahun. Angka nasional menunjukkan 71,35\% sedangkan Provinsi Bengkulu sebesar 61,67\% proporsi remaja pernah mendengar, melihat atau membaca tentang pembangunan keluarga dan 13,27\% pernah mendengar, melihat atau membaca tentang Generasi Berencana (GenRe) (Nasional 12\%), pernah mendengar, melihat atau membaca informasi berkaitan dengan PIK-R 22,4\%, remaja yang pernah mengakses akun PIKR $14,5 \%$ serta pernah mendatangi secretariat/ruang PIK-R hanya sebesar $14,7 \%$. Remaja di Bengkulu sebesar 13,7\% setuju dan sangat setuju menikah sebelum 21 tahun, $28,2 \%$ remaja setuju dan sangat setuju memiliki sikap keluarga memiliki $>2$ anak, Bengkulu memiliki indeks pendapat pengendalian kelahiran $64,4 \%$, indeks pendapat menikah sebelum 21 tahun $61,8 \%$ dan indeks memiliki banyak anak 49,5\% di atas angka nasional (49\%)(SKAP, 2019).

Wanita menikah pada usia dibawah 16 tahun selama tiga tahun terakhir selalu ada peningkatan sebagai berikut 16,17\% (2017), 16,66\% (2018), dan 17,24\% (2019), dari data tersebut pada tahun 2019 data perempuan yang menikah pada usia di bawah umur 16 tahun tertinggi di Kabupaten Muko-muko (28,38\%), disusul Bengkulu Tengah $(27,27 \%$, Kabupaten Kepahiang (21,11\%), Seluma 19,49\%). Kabupaten 
Rejang Lebong (18,58\%), Kabupaten Lebong (17,3\%), Kabupaten Bengkulu Selatan 16,27\%, Kabupaten Kaur (16,07\%), Kabupaten Bengkulu Utara (14,76\%), dan yang terendah yakni $7,16 \%$ (BPS, 2019). Penelitian ini bertujuan diketahui faktor pendukung yang berpengaruh terhadap pendewasaan usia perkawinan remaja melalui pendekatan keluarga dari segi jenis kelamin, tempat tinggal dan indeks kekayaan rumah tangga.

\section{METODE PENELITIAN}

Desain cross sectional pendekatan desain yang digunakan pada penelitian. Data Sekunder Survey Kinerja dan Akuntabilitas Program KKBPK (SKAP) Remaja, Keluarga, dan Wanita Usia Subur yang digunakan pada penelitian ini yang diselenggarakan oleh Badan Kependudukan dan Keluarga Berencana Nasional (BKKBN) dan Badan Pusat Statistik (BPS) dimana yang bertanggung jawab atas SKAP tahun 2019 adalah Pusat Penelitian dan Pengembangan KB dan KS. Survei Indikator Kinerja Program KKBPK (SRPJMN) diganti dengan survey berskala nasional yang representative provinsi yang dilakukan setiap tahun yaitu SKAP. Instrument penelitian menggunakan instrument/kuesioner SKAP 2019 Provinsi Bengkulu. Data sekunder SKAP 2019 yang digunakan dalam penelitian ini adalah kuesioner yang berhubungan dengan PUP terdiri dari variabel dependen pendewasaan usia perkawinan yakni umur dimana remaja merencanakan untuk menikah dan variabel independen yakni jenis kelamin, tempat tinggal dan indek kekayaan rumah tangga yang diukur dari tingkat kekayaan dari keluarga yang disesuaikan dengan pengukuran hasil tingkat kesejahteraan data SKAP 2019 Provinsi Bengkulu yang didapatkan dari informasi terkait kepemilikian aset keluarga. Populasi penelitian merupakan remaja berumur diantara 10-24 tahun belum menikah berhasil diwawancarai di Indonesia adalah 41.582 orang. Sampel penelitian merupakan remaja berumur 10-24 tahun belum menikah di Provinsi Bengkulu adalah 341 orang dengan kriteria remaja anak kandung yang tinggal satu rumah dengan ibu pada saat diwawancarai pada SKAP 2019 Provinsi Bengkulu. Analisis data terdiri dari dua tahapan yakni analisis univariabel dan bivariabel yang digunakan adalah chi-square.

\section{HASIL PENELITIAN}

Analisis univariabel pendewasaan usia perkawinan remaja di Provinsi Bengkulu terlihat pada Gambar 1, pengkategorian pendewasaan usia perkawinan terdiri dari 2 yaitu apabila seorang remaja perempuan yang berencana menikah lebih dari 21 tahun dan lebih dari 25 tahun untuk laki-laki maka dikategorikan baik namun apabila remaja perempuan merencanakan nikah berusia kurang dari 21 tahun dan kurang dari 25 tahun laki-laki dikategorikan kurang berdasarkan PUP dari BKKBN 2010. Hasil penelitian menunjukkan remaja dengan kategori baik sebesar $71,6 \%$ atau 244 orang remaja dan sisanya $28,4 \%$ atau 97 orang remaja dikategori kurang dalam merencanakan usia menikah di masa yang akan datang.

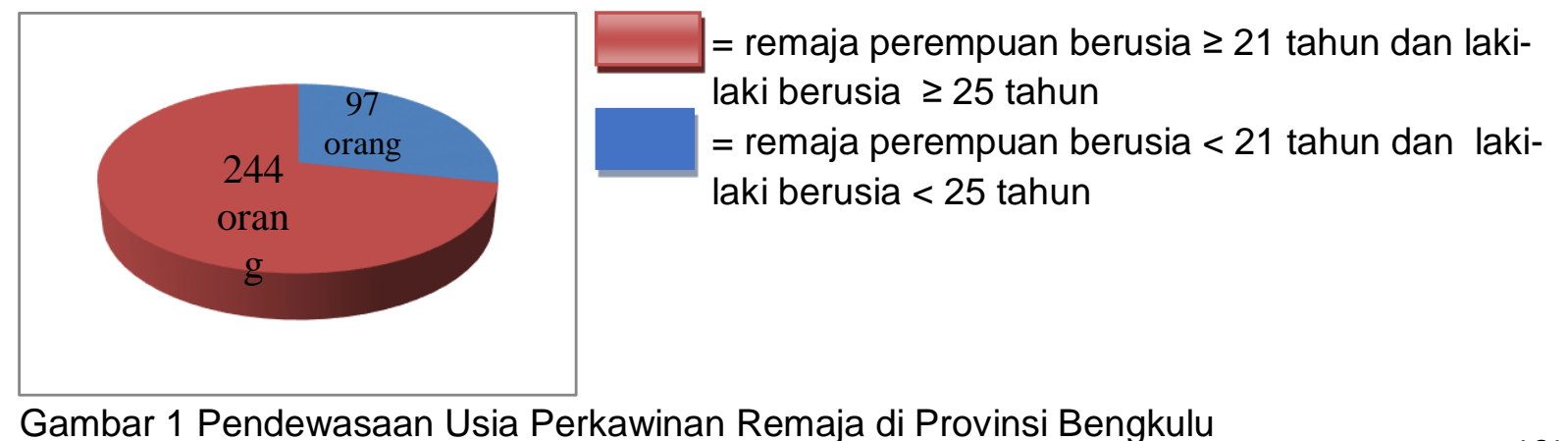

Gambar 1 Pendewasaan Usia Perkawinan Remaja di Provinsi Bengkulu 
Tabel 1. Analisis Univariat Pendewasaan Usia Perkawinan Provinsi Bengkulu

\begin{tabular}{lrr}
\hline \multicolumn{1}{c}{ Variabel } & $\mathbf{n ~ ( 3 4 1 )}$ & $\%$ \\
\hline Jenis Kelamin & & \\
$\quad$ Perempuan & 161 & 47.21 \\
Laki-laki & 180 & 52.79 \\
\hline Tempat Tinggal & & \\
$\quad$ Perkotaan & 119 & 34.89 \\
Pedesaan & 222 & 65.11 \\
\hline Indeks Kekayaan Rumah Tangga & & \\
$\quad$ Rendah & 55 & 16.12 \\
Menengah & 257 & 75.36 \\
Tinggi & 29 & 8.5 \\
\hline
\end{tabular}

Sumber: Data sekunder SKAP Remaja BKKBN Bengkulu, 2019

Hasil analisis menunjukkan remaja berusia 10-24 tahun di Provinsi Bengkulu sebagian besar $52.79 \%$ berjenis kelamin laki-laki. Sebagian besar remaja berusia $10-$ 24 tahun bertempat tinggal di pedesaan Provinsi Bengkulu (65.11\%) dan remaja sebagian besar memiliki indeks kekayaan rumah tangga berada pada tingkat kesejahteraan menengah (75.36\%).

Tabel 2. Faktor Pendukung Pendewasaan Usia Perkawinan Provinsi Bengkulu

\begin{tabular}{|c|c|c|c|c|c|c|c|c|}
\hline \multirow{3}{*}{ Variabel } & \multicolumn{4}{|c|}{$\begin{array}{c}\text { Pendewasaan Usia } \\
\text { Perkawinan }\end{array}$} & \multirow{2}{*}{\multicolumn{2}{|c|}{ Total }} & \multirow{3}{*}{$\begin{array}{c}P \\
\text { Value }\end{array}$} & \multirow{3}{*}{$\begin{array}{c}\text { OR } \\
\text { (CI 95\%) }\end{array}$} \\
\hline & \multicolumn{2}{|c|}{ Kurang } & \multicolumn{2}{|c|}{ Baik } & & & & \\
\hline & $\mathbf{n}$ & $\%$ & $\mathbf{n}$ & $\%$ & $\mathbf{N}$ & $\%$ & & \\
\hline \multicolumn{9}{|l|}{ Jenis Kelamin } \\
\hline $\begin{array}{l}\text { Perempuan } \\
\text { Laki-laki }\end{array}$ & $\begin{array}{l}35 \\
62\end{array}$ & $\begin{array}{l}21.7 \\
34.4\end{array}$ & $\begin{array}{l}126 \\
118\end{array}$ & $\begin{array}{l}78.3 \\
65.6\end{array}$ & $\begin{array}{l}161 \\
180\end{array}$ & $\begin{array}{l}100 \\
100\end{array}$ & 0.013 & $\begin{array}{c}1,89 \\
(1,16-3,07)\end{array}$ \\
\hline \multicolumn{9}{|c|}{ Tempat Tinggal } \\
\hline Perkotaan & 32 & 26.9 & 87 & 73.1 & 119 & 100 & 0.734 & 0,88 \\
\hline Pedesaan & 65 & 29.3 & 157 & 70.7 & 222 & 100 & & $(0,54-1,46)$ \\
\hline \multicolumn{9}{|c|}{ Indeks Kekayaan } \\
\hline Keluarga & & & & & & & & 1,4 \\
\hline Rendah & 19 & 34.5 & 36 & 65.5 & 55 & 100 & 0.491 & $(0,77-2,69)$ \\
\hline Menengah & 69 & 26.8 & 188 & 73.2 & 257 & 100 & & 1,1 \\
\hline Tinggi & 9 & 31.0 & 20 & 69.0 & 29 & 100 & & $(0,44-2,98)$ \\
\hline TOTAL & 97 & 28.4 & 244 & 71.6 & 341 & 100 & & \\
\hline
\end{tabular}

Sumber: Data sekunder SKAP Remaja BKKBN Bengkulu, 2019

Tabel 1 analisis bivariabel dengan menggunakan chi square menunjukkan bahwa dari dari 161 remaja dengan jenis kelamin perempuan, sebanyak 126 orang $(78,3 \%)$ perempuan memiliki rencana menikah pada saat berusia $\geq 21$ tahun dan lakilaki berusia 25 tahun. Dari 222 remaja yag tinggal di pedesaan, sebanyak 65 orang $(29,3 \%)$ perempuan memiliki rencana menikah pada saat berusia $<21$ tahun dan lakilaki berusia <25 tahun. Dari 257 remaja dengan indeks kekayaan menengah, sebanyak 188 orang $(73,2 \%)$ perempuan memiliki rencana menikah pada saat berusia $\geq 21$ tahun dan laki-laki berusia $\geq 25$ tahun. Analisis dilanjutkan menunjukkan faktor pendukung yang berhubungan yaitu jenis kelamin remaja $(p=0,009)$ dengan pendewasaan usia perkawinan pada remaja, serta faktor pendukung yang tidak berhubungan pendewasaan usia perkawinan pada remaja di Provinsi Bengkulu yaitu tempat tinggal remaja $(p=641)$ dan indeks kekayaan remaja $(p=0.491)$. 


\section{PEMBAHASAN}

\section{Jenis Kelamin Remaja}

Penelitian menunjukkan jenis kelamin berhubungan dengan pendewasaan usia perkawinan $(p=0.013)$, penelitian Ma'arif (2018) menunjukkan sejalan dengan penelitian ini yaitu proporsi jenis kelamin terbanyak adalah perempuan (Fitria Ma'arif, 2018). Pengetahuan remaja perempuan dan remaja laki-laki terkait usia perkawinan terdapat perbedaan persentase, sebanyak $33,5 \%$ remaja laki-laki mendukung pernikahan dini sedangkan $76,5 \%$ remaja wanita memiliki sikap mendukung pernikahan dini. Dengan demikian, remaja dengan jenis kelamin perempuan lebih cenderung mendukung menikah pada saat usia muda (Kusumaningtyas, Pipitcahyanu, \& Chayaya, 2019).

Penelitian Adam (2019) menunjukkan penyebab utama pernikahan usia muda adalah faktor ekonomi dan pengaruh teman sebaya (Adam, 2019). Didukung oleh penelitian terdahulu remaja perempuan yang tidak menunda usia perkawinan terjadi karena perekonomian keluarga yang tergolong menengah ke bawah yang mempengaruhi terputusnya kelanjutan pendidikan anak sehingga menikah dianggap sebagai solusi untuk mengurangi beban orang tua. Seorang laki-laki sebelum memutuskan untuk menjalani kehidupan berumah tangga sebagai modal diperlukannya keterampilan dalam untuk memenuhi kebutuhan rumah tangga nantinya. Faktor lainnya yaitu karena lingkungan sosial (teman sebaya), banyak teman sebaya remaja menikah mempengaruhi remaja lain yang sudah tidak bersekolah atau putus sekolah memutuskan untuk menikah diakrenakan adanya kecemasan dari remaja akan menjadi perawan tua apabila tidak segera menikah. Keinginan orang tua yang berkeinginan mempunyai cucu juga menjadi faktor pendorong seorang remaja memutuskan untuk menikah dini (Pratiwi, Angraini, Padila, Nopiawati, \& Yandrizal, 2019). Penelitian lebih lanjut menunjukan remaja yang memiliki teman sebaya yang berperan negatif berpeluang 2,7 kali lebih memungkinkan untuk berperilaku seksual sebelum menikah (pranikah) yang memicu terjadinya pernikahan usia muda (Aprianti, Nursal, \& Pradipta, 2020).

Hasil penelitian sebelumnya menunjukan bahwasanya berniat untuk menunda usia pernikahan. Namun, bagi mereka dengan status ekonomi rendah cenderung menjadi penentu utama usia pernikahan. Selain itu, keyakinan agama dan kesulitan sosial ekonomi membuat keluarga peserta lebih memilih anak perempuan mereka segera menikah. Dalam keluarga miskin, anak perempuan juga lebih memilih untuk menikah karena melarikan diri dari kesulitan sosial ekonomi (Montazeri, Gharacheh, Mohammadi, Alaghband Rad, \& Eftekhar Ardabili, 2016).

Penelitian sebelumnya menunjukan terdapat sebanyak $50 \%$ remaja perempuan memiliki pengetahuan yang cukup baik tentang pendewasaan perkawinan. Perempuan dalam kenyataannya masih banyak yang memutuskan untuk menikah pada saat masih berusia muda (Dini \& Nurhelita, 2020). Perempuan yang memutuskan untuk menikah pada saat usia muda akan lebih tinggi berisiko mengalami kematian akibat adanya masalah pada saat masa kehamilan dan pada saat melahirkan dibandingkan dengan perempuan yang menikah pada saat dewasa. Seorang perempuan sangat disarankan untuk menunda perkawianannya sampai dengan pada saat mereka berusia $\geq 21$ tahun dimana pada saat usia ini perempuan sudah dianggap sempurna dan siap dari segala aspek kesehatan, mental dan 
emosional. Selain itu, pengetahuan remaja, umur menarche dan media adalah faktor yang mempenagruhi ketika seseorang remaja untuk memutuskan pernikahan pada usia dini. Remaja dengan umur menarche yang masih muda akan berpengaruh terhadap semakin cepat pula ia akan untuk menikah diusia dini dikarenakan mereka merasa sudah menstruasi dan dianggap sudah cukup matang untuk bereproduksi (Angraini et al., 2019).

\section{Tempat Tinggal Remaja}

Tempat tinggal tidak berhubungan dengan pendewasaan pada perkawinan pada penelitian yang seiring dengan penelitian Follona, et al (2014) yang menunjukkan peningkatan pengetahuan terkait pendewasaan usia perkawinan tidak ada berbeda antara remaja yang bertempat tinggal di perkotaan dan pedesaaan setelah pendidikan kelompok sebaya (Follona, Raksanagara, \& Purwara, 2014). Penelitian dilakukan dengan analsiis lanjut didapatkan remaja yang tinggal di darah perdesaan 0,88 kali ( $\mathrm{Cl}$ 95\%: 0,54-1,46) dibandingkan dengan remaja yang bertempat tinggal di daerah kota memiliki rencana menikah sebelum 21 tahun dan sebelum 25 tahun untuk alki-laki. Wilayah perkotaan perempuan memiliki usia kawin pertama lebih tinggi dibandingkan dengan dari wilayah pedewasaan. Perempuan yang bertempat tinggall di wilayah perkotaan memiliki kecenderungan menikah pada saat usia lebih tua sedangan perempuan bertempat tinggal di pedesaan cenderung tidak memiliki perbedaan usia kawin (Qibtiyah, 2014). Perempuan Indonesia yang tinggal di wilayah desa 2 kali lebih berkemungkinan berencana menikah muda dibandingkan dengan perempuan yang tinggal di wilayah kota (UNICEF et al., 2020). Pernikahan dini di kalangan anak perempuan yang tinggal di perdesaan adalah akibat dari budaya dan kondisi sosial yang meyakini bahwa pernikahan akan melindungi anak dari kejahatan dan untuk menhindari perzinahan (Sudarso, Mas'udah, \& Budirahayu, 2020).

Meskipun Undang-Undang Nasional mengenai pendewasaan usia perkawinan telah lama berlaku. Namun, pola pernikahan usia anak tetap terjadi di beberapa bagian Indonesia. Penelitian Colquhoun dan Nilan (2020) menunjukan bahwa terdapat enam anak laki-laki Sasak di perdesaan Lombok Utara Nusa Tenggara Barat menikah di usia remaja ( $<25$ tahun). Kondisi ini terjadi karena diperkuat oleh adat setempat, norma dan praktik pernikaha islam dibandingkan arahan legislatef pemerintahan yang jauh dari pusat perkotaan (Jakarta) (Colquhoun \& Nilan, 2020). Sebagian besar wanita diwilayah perdesaan melakukan hubungan seksual (62\%) dibandingkan dengan yang tinggal diperkotaan (54\%). Hal tersebut karena pendidikan seksual dan layanan kesehatan reproduksi di Amerika Serikat belum mempertimbangkan tempat tinggal (desa-kota) (Janis, Ahrens, \& Ziller, 2019). Cakupan Komunikasi, Informasi dan Edkuasi yang masih rendah terkait kesehatan reproduksi dan perencanaan berkeluarga untuk remaja bertempat tinggal di wilayah perdesaan mempengaruhi ketidaktahuan remaja dalam penundaan usia perkawinan.

\section{Indeks Kekayaan Remaja}

Indeks kekayaan rumah tangga remaja tidak berhubungan dengan pendewasaan usia perkawinan. Penelitian Hardiani dan Junaidi (2018) menunjukkan tidak sejalan dengan penelitian ini yang menyatakan bahwa $23,85 \%$ wanita menikah dini berasal dari keluarga dengan orang tua yang menganggur (ayah dan ibu) berarti 
bahwa mereka tidak bekerja tetap, sehingga tidak ada jaminan penghasilan untuk memenuhi kebutuhan keluarga. Penelitian ini dianalisis lanjut didapatkan secara berurutan remaja yang indeks kekayaan keluarga rendah 1,4 kali $(\mathrm{Cl} 95 \%$ : 0,77-2,69 dan 1,1 kali (Cl 95\%: 0,44-2,98) lebih berisiko berencana menikah saat perempuan berusia $<21$ tahun dan $<25$ tahun laki-laki dibandingkan dengan remaja yang memiliki indek kekayaan keluarga tinggi dan indeks keluarga sedang. Proporsi ini tiga kali lebih tinggi dibandingkan dengan perempuan menikah pada usia dewasa. Orang tua yang memiliki pekerjaan artinya status ekonomi keluarganya akan lebih baij dibandingkan dengan orang tua yang tidak memiliki pekerjaan (pengangguran), karena itu anak perempuan dalam keluarga dengan orang tua pengangguran memiliki risiko lebih tinggi berencana menikah diusia dini dibandingkan dengan keluarga yang memiliki orang tua bekerja (Hardiani \& Junaidi, 2018).

Penelitian Pohan (2017) menunjukkan status ekonomi berhubungan dengan kejadian pernikahan di usia muda ( $p$-value $=0,003$ ), remaja perempuan yang berada pada status ekonomi keluarga rendah berisiko 3,28 kali akan menikah pada saat berumur muda dibandingkan remaja dengan status ekonomi keluarga berada pada tingkat tinggi (Pohan, 2017). Penelitian Riany, et al (2020) seiring dengan penelitian ini yang menunjukkan penghasilan orang tua akan berpengaruh terhadap perniakahan usia dini (Riany, Yanuarti, Pratiwi, \& Angraini, 2020).

Usia Kawin Pertama (UKP) remaja berpengaruh positif terhadap status sudah memiliki pekerjaan. Wanita yang telah memiliki pekerjaan sebelum menikah akan memiliki UKP lebih tinggi dibandingkan dengan wanita yang belum bekerja (Utina, Baderan, \& Pongoliu, 2014). Pendapatan keluarga memiliki keeratan dengan usia nikah pertama, apabila pendapatan keluarga rendah maka akan semakin cepat (dini) pihak keluarga untuk memutuskan menikahkan anak perempuannya. Usia nikah muda dipengaruhi oleh tingkat pendapatan keluarga, tingkat pendapatan keluarga yang berada pada tingkat rendah beranggapan dengan menikahkan anaknya secepat mungkin maka terlepas jugalah beban dan tanggung jawab orang tua untuk menghidupi anaknya (Kurniawati, Nurrochmah, \& Katmawanti, 2017). Pekerjaan, pendidikan dan sikap penggunaan Keluarga Berencana merupakan faktor yang mempengaruhi pemilihan metode kontrasepsi pada pasangan usia subur sebagai upaya untuk masa depan para remaja yang telah memutuskan untuk menikah muda (Febriawati, Ekoriano, Angraini, Purwoko, \& Suryani, 2021). Dengan demikian, remaja yang memiliki keluarga dengan status ekonomi pada tingkatan tinggi makan akan semakin tinggi pula indeks kekayaan yang akan diperoleh remaja maka kemungkinan besar akan semakin remaja menunda usia perkawinannya.

\section{SIMPULAN DAN SARAN}

Pendewasaan usia perkawinan remaja di Provinsi Bengkulu menunjukkan sebagian besar remaja $(71,6 \%)$ perempuan berniat untuk nikah di saat berusia $\geq 21$ tahun dan laki-laki saar berusia $\geq 25$ tahun. Jenis kelamin merupakan faktor pendukung atau yang memungkinkan remaja untuk menunda usia pernikahan. Tempat tinggal remaja dan indeks kekayaan rumah tangga remaja tidak berhubungan dengan usia perkawinan remaja di Provinsi Bengkulu. Dengan demikian, perlu dilakukannya intervensi terkait pendewasaan usia perkawinan dan risiko kesehatan apabila menikah pada saat usia muda melalui Komunikasi, Informasi, dan Eduaksi (KIE) kepada masyarakat khususnya para remaja yang yang bertempat tinggal di wilayah pedesaan, guna mencegah semakin banyaknya praktik pernikahan di usia anak. 


\section{UCAPAN TERIMA KASIH}

Penulis mengucapkan terima kasih kepada Pusat Penelitian dan Pengembangan KB dan KS Badan Kependudukan dan Keluarga Berencana Nasional (BKKBN) atas dukungannya melalui hibah penelitian ini.

\section{DAFTAR PUSTAKA}

Adam, A. (2019). Dinamika Pernikahan Dini. Al-Wardah: Jurnal Kajian Perempuan, Gender Dan Agama, 13(1), 15-23. Retrieved from http://journal.iainternate.ac.id/index.php/alwardah/article/view/155

Angraini, W., Pratiwi, B. A., Febriawati, H., Yanuarti, R., Anita, B., \& Oktarianita, O. (2019). Faktor yang Mempengaruhi Terjadinya Pernikahan Usia Dini. Jurnal Biometrika Dan Kependudukan, 8(2), 183-191. https://doi.org/10.20473/jbk.v8i2.2019.183-191

Aprianti, Nursal, D. G. A., \& Pradipta, Y. (2020). Reinforcing Faktor Perilaku Seks Pranikah pada Remaja SMA Favorit di Kota Padang. Media Kesehatan Masyarakat Indonesia, 16(2), 171-182. https://doi.org/10.30597/mkmi.v16i2.9046

Badan Kependudukan dan Keluarga Berencana Nasional (BKKBN). (2010). Peraturan Kepala Badan Koordinasi Keluarga Berencana Nasional Nomor 55/HK-010/135/2010 tentang Standar Pelayanan Minimal Bidang Keluarga Berencana dan Keluarga Sejahtera di Kabupaten/Kota. Jakarta.

BPS. (2019). Statistik Kesejahteraan Rakyat Provinsi Bengkulu 2019. Bengkulu: Badan Pusat Statistik. Retrieved from https://bengkulu.bps.go.id/publication/2019/12/30/edd1971fe4a1e1e4ab9ba71 e/statistikkesejahteraan-rakyat-provinsi-bengkulu-2019.html

Colquhoun, L., \& Nilan, P. (2020). Early Marriage Among Sasak Boys in Rural North Lombok. Jurnal Studi Pemuda, 9(2), 150-162. https://doi.org/10.22146/studipemudaugm.56370

Dini, A. Y. R., \& Nurhelita, V. F. (2020). Hubungan Pengetahuan Remaja Putri tentang Pendewasaan Usia Perkawinan terhadap Resiko Pernikahan Usia Dini. Jurnal Kesehatan, 11(1), 50-59. Retrieved from http://jurnal.stikescirebon.ac.id/index.php/kesehatan/article/view/197

Febriawati, H., Ekoriano, M., Angraini, W., Purwoko, E., \& Suryani, I. (2021). Contraceptive Choice Among Couples of Childbearing Age (PUS) in Bengkulu Province. Jurnal Biometrika Dan Kependudukan, 10(2), 202-214. https://doi.org/10.20473/jbk.v10i2.2021.202-214

Fitria Ma'arif. (2018). Hubungan antara Tingkat Pengetahuan dan Sosial Budaya dengan Sikap Remaja Terkait Pendewasaan Usia Perkawinan. Jurnal Biometrika Dan Kependudukan, 7(1), 39-48. https://doi.org/10.20473/jbk.v7i1.2018.39-48

Follona, W., Raksanagara, A. S., \& Purwara, B. H. (2014). Perbedaan Pendidikan Kelompok Sebaya tentang Pendewasaan Usia Perkawinan di Perkotaan dan Perdesaan. Kesmas: National Public Health Journal, 9(2), 157. https://doi.org/10.21109/kesmas.v9i2.518

Hardiani, \& Junaidi. (2018). Determinants of Early Marriage and Model of Maturing Marriage Age Policy. Innovative Issues and Approaches in Social Sciences, 11(1). Retrieved from https://ideas.repec.org/p/pra/mprapa/86453.html

Istawati, R. (2019). Hubungan Pengetahuan dengan Sikap Remaja Putri tentang Pendewasaan Usia Perkawinan di M.A Pondok Pesantren Teknologi. Jurnal IImu Kebidanan (Journal of Midwifry Sciences), 8(1), 34-39. Retrieved from https:/jurnal.stikes-alinsyirah.ac.id/index.php/kebidanan/article/view/120

Janis, J. A., Ahrens, K. A., \& Ziller, E. C. (2019). Female Age at First Sexual Intercourse by Rural-Urban Residence and Birth Cohort. Women's Health Issues, 29(6), 489-498. https://doi.org/10.1016/j.whi.2019.07.004

Khayati, Y. N., Sundari, \& Dewi, M. K. (2020). Mencegah Pernikahan Usia Dini Melalui Pendewasaan Usia Perkawinan pada Siswa MA Tarbiyatul Islamiyah Lengkong, Batangan, Pati. Indonesian Journal of Community Empowerment (IJCE), 2(1), 32-37. Retrieved from http://jurnal.unw.ac.id:1254/index.php/IJCE/article/view/520 
Kurniawati, L., Nurrochmah, S., \& Katmawanti, S. (2017). Hubungan antara Tingkat Pendidikan, Status Pekerjaan dan Tingkat Pendapatan dengan Usia Perkawinan Pertama Wanita di Kelurahan Kotalam Kecamatan Kedungkandang Kota Malang. Jurnal Preventia, 2(1), 210-219. https://doi.org/10.17977/um044v1i2p210-219

Kusumaningtyas, K., Pipitcahyanu, T. I., \& Chayaya, I. H. (2019). Comparison of Knowledge about Early Marriage between Young Men and Women. Aloha International Journal of Education Advancement (AIJEA), 1(3), 34-36. Retrieved from http://journal.aloha.academy/index.php/aijea/article/view/aijea10203

Montazeri, S., Gharacheh, M., Mohammadi, N., Alaghband Rad, J., \& Eftekhar Ardabili, H. (2016). Determinants of Early Marriage from Married Girls' Perspectives in Iranian Setting: A Qualitative Study. Journal of Environmental and Public Health, 1-8. https://doi.org/10.1155/2016/8615929

Pohan, N. H. (2017). Faktor yang Berhubungan dengan Pernikahan Usia Dini terhadap Remaja Putri. Jurnal Endurance, 2(3), 424-435. Retrieved from http://ejournal.Ildikti10.id/index.php/endurance/article/view/2283

Pratiwi, B. A., Angraini, W., Padila, Nopiawati, \& Yandrizal. (2019). Analisis Pernikahan Usia DIni di Kabupaten Bengkulu Tengah Tahun 2017. Jurnal Kesmas Asclepius (JKA), 1(1), 14-24. https://doi.org/10.31539/jka.v1i1.575

Qibtiyah, M. (2014). Faktor yang Mempengaruhi Perkawinan Muda Perempuan. Jurnal Biometrika Dan Kependudukan, 8(1), 50-58. Retrieved from http://journal.unair.ac.id/download-fullpapers-biometrik289f6d5a6dfull.pdf

Riany, E., Yanuarti, R., Pratiwi, B. A., \& Angraini, W. (2020). Faktor-Faktor yang Berpengaruh terhadap Pernikahan Usia Dini. Journal of Telenursing (JOTING), 2(2), 158-167. https://doi.org/10.31539/joting.v2i2.1631

SKAP. (2019). Survei Kinerja dan Akuntabilitas Program KKBPK (SKAP) Keluarga. Badan Kependudukan Dan Keluarga Berencana Nasional. Jakarta.

Sudarso, S., Mas'udah, S., \& Budirahayu, T. (2020). Early Marriage and Women 's Empowerment in Rural Areas. International Journal of Innovation, Creativity and Change, 13(3), 896-912. Retrieved from https://repository.unair.ac.id/107534/

UNICEF, Badan Pusat Statistik (BPS), \& Badan Perencanaan Pembangunan Nasional (Pappenas). (2020). Pencegahan Perkawinan Anak Percepatan yang Tidak Bisa Ditunda. Retrieved from https://www.unicef.org/indonesia/media/2851/file/ChildMarriage-Report-2020.pdf

Utina, R., Baderan, D. W. K., \& Pongoliu, Y. I. (2014). Kajian Faktor Sosial Ekonomi yang Berdampak pada Usia Perkawinan Pertama di Provinsi Gorontalo (Universitas Negeri Gorontalo). Universitas Negeri Gorontalo. Retrieved from https://repository.ung.ac.id/karyailmiah/show/333/kajian-faktor-sosial-ekonomi-yangberdampak-pada-usia-perkawinan-pertama-di-provinsi-gorontalo.html 